\title{
Give the members what they want: Results of ACRL's membership
}

\section{survey}

\author{
By JoAn S. Segal
}

Executive Director, ACRL

\section{Who we are and what we do.}

\section{A}

ccording to a recent survey conducted for the Association of College and Research Libraries (ACRL), the typical ACRL member is an administrator in a university library. She has been a member 8.5 years, belongs to her state library association, and is eligible for tenure. She regularly reads half or more of her $C \mho R L$ and $C \mathcal{U} R L$ News issues. She is responsible directly or indirectly for a budget of almost $\$ 750,000$, buying books and serials, furniture and equipment, supplies, and automation hardware and software. Although she has not attended an ACRL National Conference, she believes they should be held more frequently than every three years. She has taken part in an ACRL-sponsored educational activity and would be interested in one in the future. She attends chapter meetings regularly or occasionally. She is almost 45 years old and holds the MLS degree, but has not served on an ACRL committee, section committee, editorial board, or the Board of Directors.

\section{Objectives}

The ACRL commissioned Research USA, Inc., to conduct the survey of a sample of its current members in the fall of 1989 , to find out more about them, their libraries, and their involvement with
ACRL. Some of the specific areas studied in the survey included:

- Type and place of employment

- Memberships within ALA and other discipline-related association.

- Critical issues facing libraries

- Value of ACRL activities

- Readership of ACRL publications

- Purchasing involvement and budget responsibility

- Attendance at National Conferences

- Interest in educational activities

- Contacts with ACRL

- Local chapter membership

- Participation in discussion groups

- Demographic characteristics

\section{Methodology}

Six hundred names were selected from the ACRL membership list on an $n t h$ name basis. On October 3, 1989, a postcard announcing the survey was mailed to each one over the name of William A. Moffett, ACRL president, asking for their cooperation. On October 6, 1989, a four-page questionnaire was mailed to each name, together with a cover letter from Research USA, a one-dollar bill, and a stamped return envelope. One week later, a 


\title{
Membership in other Organizations
}

\author{
1989 ACRL Membership Survey
}

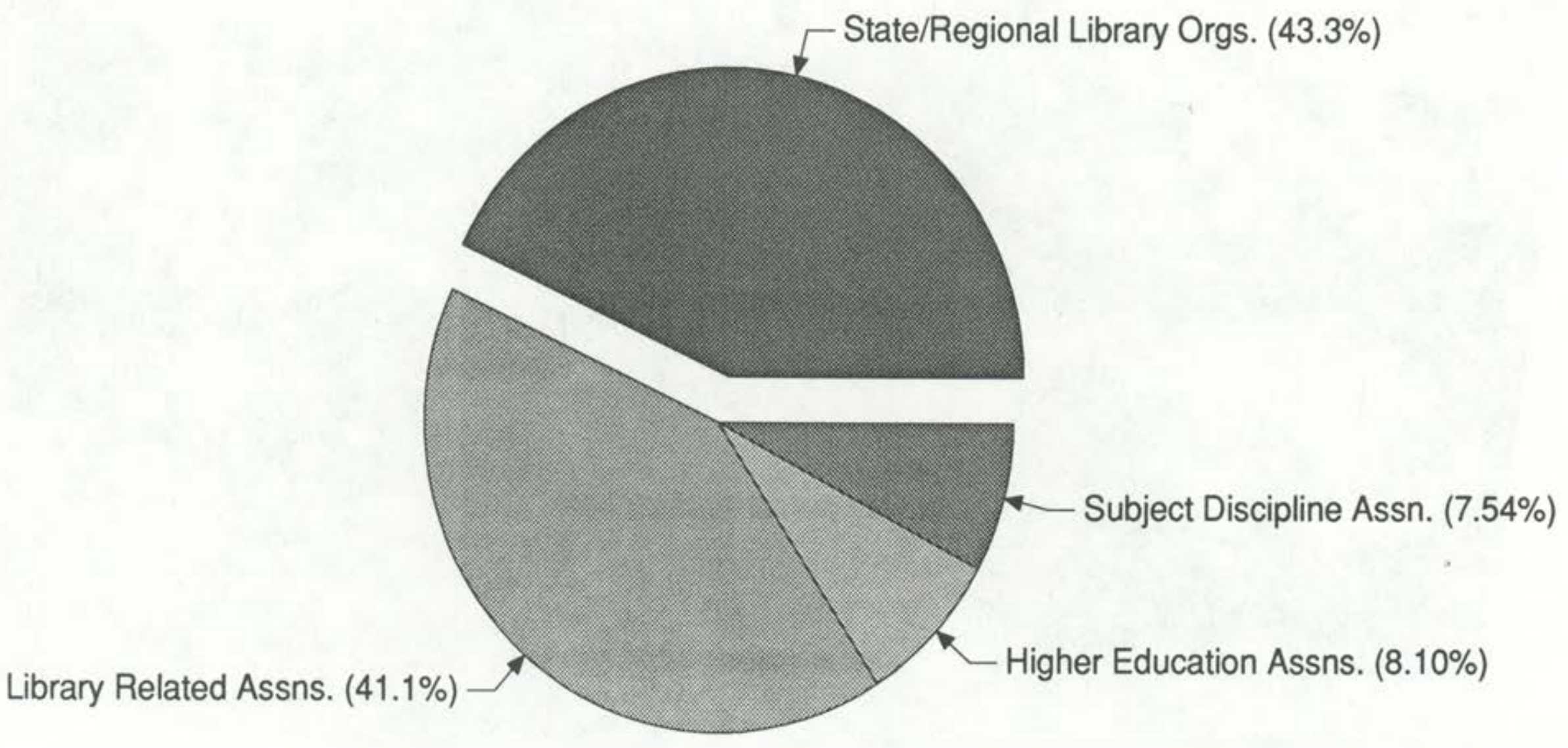

second questionnaire with another cover letter and return envelope was mailed. It asked for responses from those who had not yet returned the survey, and thanked those who had already responded.

By November 10, 1989, 468 questionnaires had been completed and returned, or 79.5\% Results are projectable within a range of $\pm 5 \%$ (with $95 \%$ confidence).

\section{Results}

Results show that $47.2 \%$ of ACRL members are employed at a research/doctoral-granting university, $23.7 \%$ work in a four-year college, $7.9 \%$ in a community or junior college, and $21 \%$ in other environments, including special or public libraries or library-related businesses. Thirty-eight percent of the sample are administrators, $28.9 \%$ work in public services, $15.8 \%$ in technical services, and $15.1 \%$ in collection development. The average length of membership is 8.5 years, but $12.7 \%$ have been members for twenty years or more.

A total of $93.8 \%$ of the respondents asserted they read $C \& R L$ regularly ( 3 out of 4 issues); $89.9 \%$ said they read C\&RL News with similar frequency. $39.8 \%$ read Choice, and $39.4 \%$ their section newsletters. $78 \%$ said they read half or more of each issue of $C \mho R L$ and $85.1 \%$ said the same of $C \triangleleft R L$ News. Only $1.1 \%$ of respondents read none of ACRL's serial publications.

The demographics have changed slightly over the past five years. Membership is $60.4 \%$ female (in
1985 , it was $65 \%)$. The average age is 44.8 and the bulk of the members are between 35 and 54 . An overwhelming $88 \%$ hold the MLS; $32.9 \%$ have a second master's, and $15.5 \%$ a Ph.D.

There is over $20 \%$ overlap with each of the following other ALA divisions: ALCTS, RASD, LITA, and LAMA. As many as $55.8 \%$ belong to their state library organization, while $42.5 \%$ said they were eligible for tenure.

Although 68\% have not attended any of ACRL's national conferences, of those who went, their libraries sent 3 to 4 people and more than half had their way paid by their libraries. They considered the program to be the most important factor in making the decision to attend; cost/benefit was the second most important, and convenience of location the third. A total of $61.4 \%$ thought ACRL should offer a national conference more often than it now does.

Of the respondents, $46.5 \%$ have taken part in an ACRL-sponsored educational activity; $83.5 \%$ said they would be interested in one in the future. They'd like something in management $(62 \%)$, technology $(59.1 \%)$, or professional development $(56 \%)$. They want the activity in their region (65.4\%), at ALA Annual Conference (44.7\%), or at a local chapter meeting (42.8\%). Among off-site delivery formats, they prefer videotape $(54 \%)$ over audio or video conferencing (28.2\%) or computerassisted instruction (28\%).

Those who have been in contact with ACRL staff $(34.9 \%)$ used the telephone $(71 \%)$ or the mail 


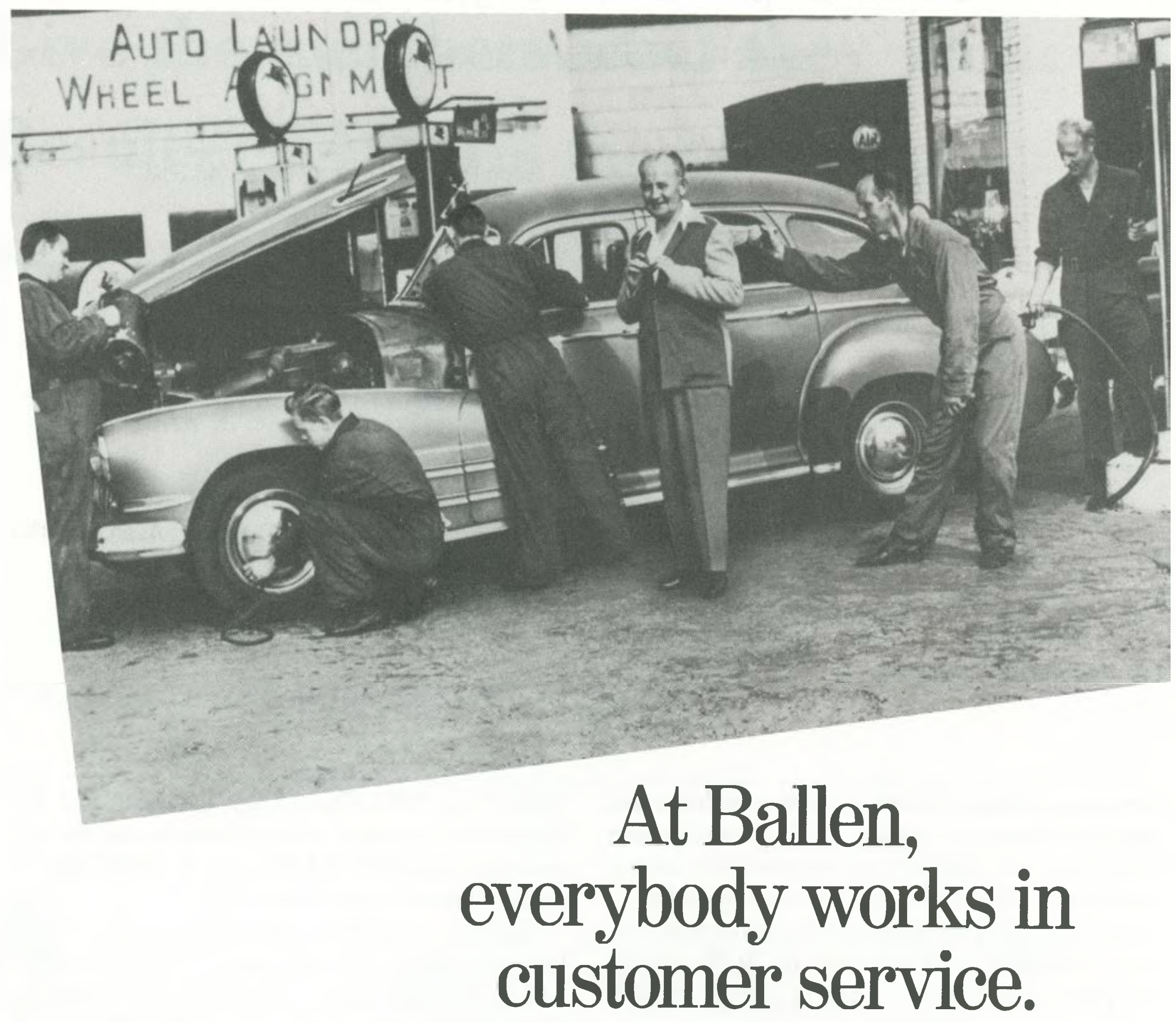

Ballen's commitment to customer service spans from the boardroom to the stockroom. It's what sets us apart from other booksellers, and a big reason why we have the highest fulfillment and lowest return rates in the industry.

Whether you're a large university, small junior college, medical school or special library, we work with you to tailor our services to your specific needs. These include our Approval Program, which is one of the most comprehensive and efficient available. Or our Firm Order Services, which produce the fastest possible response to every order, no matter how obscure the title. And our Continuation/Standing Order Services, in which no volume in any series is ever overlooked.

Our philosophy is simple: the better we serve each customer, the more customers we'll have to serve. To see the difference constant attention to customer service makes, call Ballen at 800-645-5237.

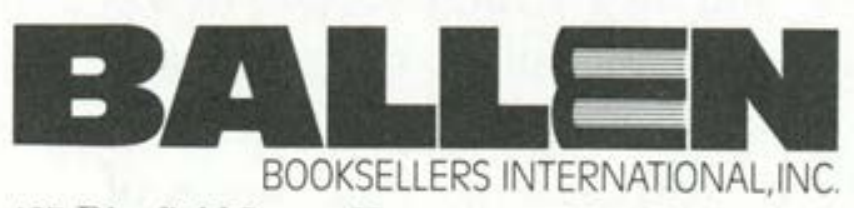

125 Ricefield Lane, Hauppauge, New York 11788 
(52.5\%); they felt their business was handled very $(75.2 \%)$ or somewhat $(21.1 \%)$ satisfactorily and characterized the contacts as quick and helpful (66.7\%).

Chapters claim only $43.2 \%$ as members; respondents attend regularly (37.4\%) or occasionally $(38.5 \%)$, and consider the meetings as of great $(25.7 \%)$ or some $(56.5 \%)$ value. Over half $(55.9 \%)$ had used the Chapters Speakers Bureau within the past two years. Discussion group activity reached only $25.8 \%$ of the members, and $23.7 \%$ of those responding had served on an ACRL committee, section committee, editorial board, or Board of Directors.

Respondents are responsible for sizable budget amounts: $15.8 \%$ were responsible for budgets over $\$ 1$ million; the average was $\$ 723,000$ and the median $\$ 161,500$. More than half of them buy books and serials, furniture and equipment, library supplies, microcomputer hardware and software for library automation; $92.9 \%$ are involved in recommending or selecting materials for their library.

\section{Issues and activities}

The top five "critical issues" identified by respondents were:

- rising journal prices $(70.9 \%)$;

- providing access to information $(48.5 \%)$;

- preservation of library materials (46.6\%);

- recruitment and retention of library staff $(35 \%)$; and

- maintaining security of collections and users (26.3\%).

Highest-ranked ACRL activities included:

- Standards and guidelines;

- job information;

- opportunities to discuss issues;

- research;

- statistics collection;

- education;

- publications;

- awards;

- advisory services; and

- liaison activities.

In reviewing ACRL activities for their fit with members' concerns, executive director JoAn Segal noted that ACRL has taken some measures in relation to all of the top five issues identified. On the topic of journal prices, it has established a discussion group and, as a result of Board action, has joined with ARL on a number of initiatives. The 1989 ACRL President's Program addressed the issue of serials pricing, with librarians from a community college, a four-year college, and a non-ARL university providing evidence that the problem is not confined to large research libraries.

ACRL has taken the lead in providing access to information for librarians through its programs of publishing and education. Although preservation falls within the bailiwick of ALCTS, ACRL's interest has been expressed through program co-sponsorship at the ALA Annual Conference in Chicago, through activity in the Rare Books and Manuscripts Section (RBMS), by honoring preservation leader Patricia Battin as Academic or Research Librarian of the Year 1990, by starting a "Preservation News" column in C\&RL News, by adding a field to Choice reviews that recognizes publications on acid-free paper, and by publishing Choice on such paper.

Recruitment of underrepresented groups, an objective in the ACRL Strategic Plan, is being addressed by a Task Force chaired by Edith Fisher. Maintaining security is an important facet of RBMS activity; members of ACRL were active in the recent apprehension of a national book thief.

\section{Summary and conclusion}

ACRL's membership survey has provided the Association with confirmation that it is "doing the right thing" and indications of areas for future

\section{Call for help: What is information literacy?}

Barbara J. Ford, ACRL vice-president/president-elect, is asking for your help in succinctly explaining the phrase "information literacy." Although the words "information literacy" are often used, the concept has eluded a short, jargon-less explanation clear to those outside the library and information science community.

Information literacy is the theme for Ford's presidential year. To increase its impact in the higher education community, Ford wants your ideas in coining a clear explanation of the concept.

Also needed are quotations from published literature or papers that articulate the concept of information literacy, and/or express the need for an information-literate society.

All suggestions or quotations will be reviewed by Ford and used as she develops her information literacy theme in 1990-1991. Projects already planned by her President's Program Planning Committee include brochures on information literacy, articles on information literacy in College \& Research Libraries News and a presentation during the 1991 ALA Annual Conference in Atlanta.

Please send your definitions and quotations as soon as possible, but not later than November 1, 1990, to Barbara J. Ford, Trinity University Library, 715 Stadium Drive, San Antonio, TX 78212. 
development. "The survey provides evidence of an intelligent, professionally committed group of members," commented Susan Stussy, director of libraries at St. Norbert College and a member of ACRL's Membership Committee, which directed staff to work on the quintennial survey.

Betsy Hine, monograph cataloger at Indiana State University, who also serves on the Membership Committee, noted "It seems to me that what
ACRL does now ranks quite high ... the membership seems fairly happy with what ACRL is doing... Response(s) reflect a very pragmatically oriented group."

As ACRL carries on its regular planning process, and as individual committees plan activities over the next years, this survey will provide a helpful guide to members' opinions.

\title{
Curriculum materials in online
}

\section{catalogs}

\author{
Developed by the \\ EBSS Curriculum Materials in the Online Catalog ad hoc Subcommittee*
}

Rolland H. McGiverin, Chair

\section{Standardized cataloging for curriculum centers.}

his paper is to assist curriculum librarians, systems personnel, and catalogers who have responsibility for preparing curriculum materials for inclusion in online catalogs in academic libraries. Curriculum materials in this document are defined as materials traditionally found in curriculum centers, e.g., curriculum guides, elementary and secondary textbooks, instructional media, and juvenile literature. This document will give an overview of the history of cataloging curriculum materials and identify cataloging issues which are unique to curriculum materials to facilitate the inclusion of these materials in online catalogs.

\section{Historical background}

In the early decades of this century, curriculum laboratories or centers were developed at various colleges of education to study, improve, revise, and produce elementary and secondary school curricula. As their products and programs became im-

${ }^{\circ}$ Editor's Note: This is a joint subcommittee of the EBSS Problems of Access and Control of Education Materials Committee and the EBSS Curriculum Materials Committee. Its members are as follows: Rolland H. McGiverin (chair), Indiana State University; Joan Berman, Humboldt State University; Doris Brookshier, Central Missouri State University; Lawrence Marble, Temple University; Virginia Nordstrom, Queens College; and Ilene Rockman (chair of the EBSS Problems of Access and Curriculum Materials Committees), California Polytechnic State University. The authors extended their appreciation to Allison Kaplan, University of Delaware, and Kathleen McGowan, University of Rochester, for their assistance in the preparation of this document. 